\title{
"LA HERENCIA DE MATILDE ARCÁNGEL": UNA LECTURA DE ANGUSTIA INVASORA
}

Lorena Vargas Mora

"El poeta quiere hacernos mirar, a nosotros mismos a través del diabólico anteojo..."

Sigmund Freud

El cuento "La Herencia de Matilde Arcángel" de Juan Rulfo está contado por un narrador: Tranquilino Herrera, un arriero quien cumple varios papeles: narrar la historia y ser partícipe de ella ocupando el espacio de un personaje: El Compadre y el pretendiente de Matilde Arcángel.

La historia se desarrolla en un pueblo llamado: Corazón de María, donde Euremio Cedillo tenía un rancho "Las Ánimas" y un hijo de igual nombre Euremio Cedillo, conocidos como "los Eremites". Viudo y huérfano respectivamente de Matilde Arcángel quien era de Chupaderos, 
hija de Sinesia dueña de la fonda. Estuvo comprometida con Tranquilino pero lo rechazó al conocer a Euremio Cedillo.

Ella pasó de ser niña querida a mujer deseada en esa comunidad hasta que se fue de alli, hasta que Euremio se la apropió, casándose con él; quizá por necesidad, o por interés o porque le atrajo su cuerpo alto y fuerte. Se conocieron porque Tranquilino la llevó a las Ánimas para presentársela como novia en compromiso a su amigo Euremio Cedillo y "al volver de mis recorridos supe que ya estaba casada con el dueño de Las Ánimas" (1, pág. 184). Parece que ella se traslada de un sitio a otro porque según se narra, Cedillo no llega a ir nunca a Chupaderos "sí acaso lo conoció fue por referencia". (1, pág.183).

Y sí parece que Matilde se alimenta mejor: "Después engordó. Tuvo un hijo. Luego murió. La mató un caballo desbocado". (1, pág. 184), así de lacónica describe la corta vida de Matilde. No así para Euremio Cedillo y su hijo, pues sus vidas desoladas por la muerte de la madre alimentada primero por el odio y luego para "la viva soledad" los condenó a una terrible sobrevivencia.

Tranquilino quiso mantenerse cerca de Matilde y bautizarle al niño era un buen motivo, y justo ese día lo estuvo como el día en que se besaron, cuando le tocó cerrarle los ojos. El caballo desbocado la dejó tirada en un charco de agua, pero quedó embrocado sobre su hijo con una expresión de contento porque aún en su final logró proteger con su cuerpo a su hijo Euremio de la caída.

Se fue feliz como madre y se quedó el odio del padre acusador del hijo pues a causa de sus berridos el caballo se asustó y corrió desbocado, condenándolo a la ira y al desamor: 
"Y yo para qué voy a quererlo. Él de nada me sirve. La otra podía haberme dado más y todos los hijos que yo quisiera, pero éste no me dejó ni siquiera saborearla". (1, pág. 186).

El niño abandonado a su suerte creció como pudo con ayuda de la compasión ajena, desnutrido y bajo a diferencia de lo grande y fuerte de su padre.

Euremio se dedicó a la bebida mientras mal vendía sus tierras a cambio de botellas de "Bingarrote" y a golpear a su hijo. El joven por su parte aprendió a tocar la flauta.

Un día llegaron unos revoltosos al pueblo y Euremio hijo, se fue con ellos al son de su música.

A los días pasaron unas tropas del gobierno y Euremio padre, lo siguió en su caballo y con el rifle en su mano.

Días después llegaron unos Coamileros y ya para la noche la música de flauta avisó la presencia de los Euremites, el joven montado en ancas, el viejo atravesado sobre la silla, muerto.

Florence Oliver en su artículo, "La seducción de los fantasmas", plantea cómo Juan Rulfo en su obra acude al interjuego de dos poderosos elementos: la seducción y el fantasma. Si entendemos la seducción como acto de persuasión en un marco de cautividad donde se sufre de una fuerte atracción con pérdida de libertad, podemos decir que en el cuento: La Herencia de Matilde Arcángel, la seducción ocurre.

Juan Rulfo nos cuenta un cuento y su arte es crear una narración fluida como un cuento y pasar de una apa- 
rente simple naturaleza del escrito a una complejísima temática en la que el lector queda atrapado en la fascinación de aquello que sucede sin poder aprehenderlo.

La trama la entretejen, sin solución evidente, uno seres de ficción que están allí presentes pero que son a la vez fantasmas, imágenes de personas muertas, imágenes impresas en la fantasía, o quizá visiones angustiosas.

Ese tránsito del fantasma que sucede o de la seducción que impide el descanso del fantasma provoca un acercamiento entre el lector y el narrador, una experiencia de intimidad; esa experiencia tan cercana conmueve a la vez con la angustia invasora de unos personajes atravesados por el dolor.

Esa extraña intimidad produce un terrible pavor en la medida en que se acerca más a los orígenes de las desgracias, que pone ahí, que nos cuenta, pero sin preocuparse por explicar, manteniendo su enigma.

A esta cautividad de la narración le subyace de acuerdo a Florence Oliver, lo UNHEIMLICHE, lo extraño familiar freudiano.

Para Freud lo "UNHEIMLICHE es lo angustioso algo que además es siniestro". (5, pág.192).

Esta palabra del idioma alemán tiene varios sentidos que se encuentran en las narraciones de Juan Rulfo. Uno de ellos se refiere a "una casa oscura llena de fantasmas"*,

* Comunicación verbal 
como puede serlo COMALA en Pedro Páramo (2, pág. 1), casa-pueblo habitada por gente muerta.

Otro de ellos es "algo desconocido que da miedo porque se sospecha que puede ser eso desconocido" **. También UNHEIMLICHE puede ser "un secreto" ***.

La seducción, el fantasma y lo siniestro ofrecen un terreno ambiguo donde caminan los personajes, por ejemplo la presencia viva de Matilde Arcángel, o la muerte que une y encierra la filiación maldita entre "los Eremites".

A la vez la ambigüedad es transitiva propiciando movimientos insospechados, desplazamientos y pérdidas de lugares.

El lugar es de importancia clave en los personajes de Rulfo y para tener mejor acceso al concepto nos quedaremos con una sutil pero a la vez sustanciosa definición filosófica "el lugar se define como un modo de ESTAR EN" (7 pág. 263).

Es posible encontrar en la relación entre padre e hijo una asombrosa inestabilidad en medio de un encarcelamiento psicológico en que sufren el discurso del otro, generándose por tanto seducciones traumáticas, esto es la violencia de la evocación.

La evocación se fija en la muerte de Matilde Arcángel, trastocándose la filiación al morir la madre y deviniendo la seducción que genera abolir al otro; cruzán-

** Comunicación verbal

*** Comunicación verbal

Ensayos Pedagógicos - 211 
dose los lugares como infanticidio para el padre como parricidio para el hijo.

La vida que temporalmente nos unió se torna muerte y el deseo del padre sucumbe al goce del odio por su hijo, como imagen en el espejo que devuelve otra rosa de los vientos que cambia y confunde los lugares, anclándose en lo siniestro. Según Freud "lo siniestro sería aquella suerte de espantoso que es propio de las cosas conocidas y familiares desde tiempo atrás" (5. Pág. 193). El espanto del odio del padre hacia el hijo: "...vivía si es que todavía vive aplastado por el odio como por una piedra..." (1. Pág. 181).

El padre odia al hijo porque según él le quita todo y al sentirse sin nada niega al hijo. Pero al negar al hijo se niega a sí mismo como hombre sujeto de placer que poseyó a la mujer y tuvo un hijo con ella. No logra observar su ley de hombre que tiene su placer, se reproduce y se recrea, sino que se devuelve a un lugar que no le pertenece para expropiar al otro de su vínculo con la madre, amargado por la envidia porque Matilde hasta la vida dio por su niño.

Estos desplazamientos rompen un orden produciéndose el "impasse incestuoso" que colige Florence Oliver (6. Pág. 619). Euremio Cedillo padre falsea la tríada al negar su placer dando lugar al goce negado del hijo. Envidian en el hijo a la madre para él y niega poseerla porque la mujer es sólo objeto-madre.

La confusión que se genera en esta filiación obliga al hijo a un esfuerzo de consumación mediante el acto parricida, porque aunque no consta en el texto que el hijo mata al padre podemos hacer una elaboración simbólica que la 
trama permite sostener. Es un esfuerzo del hijo por constituirse en sujeto.

Por otro lado, en oposición al desplazamiento de lugares sucede también la centralización de lugar, por medio de un agente que amarra desde su lugar, tanto a la historia como a los personajes: Tranquilino Herrera, cruzándose en él como en un empalme todos los involucrados. Como narrador con el lector, como arriero con su mundo concreto, como amigo de Euremio padre, como padrino de Eumerio hijo y como enamorado de Matilde Arcángel.

Contando la historia Tranquilino soporta lo siniestro de su amor quimérico, operando lo unheimliche como el secreto, "sería todo lo que debía haber quedado oculto, secreto, pero que se ha manifestado". (5 pág. 200).

En intimidad con la angustia invasora Tranquilino nos cuenta el secreto y al hacerlo puede seguir soportando la ausencia, puede darle lugar a su fantasma, permitiendo que el amor que siente por ella siga vivo, perpetuando la presencia de Matilde Arcángel. 


\section{CITAS BIBLIOGRÁFICAS}

1. RULFO, Juan.

EL LLANO EN LLAMAS

Plaza Janés. Editores Barcelona. 2000

2. RULFO, Juan.

PEDRO PARAMO

Plaza Janés. Editores. Barcelona. 2000

3. FREUD, Sigmund.

Obras Completas. EL PORVENIR DE LAS RELIGIONES.

Tomo: IX. Trad. Luis López Ballestero.

Editorial Iztaccihuatl. Sin año de publicación

4. FREUD, Sigmund.

Obras Completas. PSICOLOGÍA DE LAS MASAS Y ANÁLISIS DEL YO

Tomo: XIV. Trad. Luis López Ballestero.

Editorial Iztaccihuatl. Sin año de publicación

5. FREUD, Sigmund.

Obras Completas. PSICOANALISIS APLICADA

Tomo: XVIII. Trad. Luis López Ballestero.

Editorial Iztaccihuatl. Sin año de publicación

\section{OLIVER, Florence}

LA SEDUCCIÓN DE LOS FANTASMAS EN LA OBRA DE JUAN RULFO Artículo Fotocopiado

7. FERRATER, José

DICCIONARIO DE LA FILOSOFIA ABREVIADO

Editorial Hermes. México. 1987. 